http://kitaibelia.unideb.hu/

ISSN 2064-4507 (Online) • ISSN 1219-9672 (Print)

(C) Department of Botany, University of Debrecen, Hungary

22 (2): 272-285.; 2017

DOI: $10.17542 /$ kit.22.272

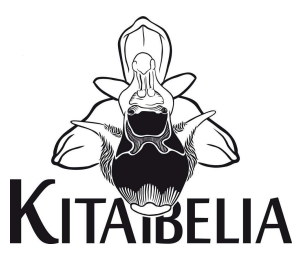

\title{
A Pseudoleskea saviana (De Not.) Latzel lombosmoha Magyarországon
}

\author{
NAGY József ${ }^{1} \&$ NÉMETH Csaba ${ }^{2}$
}

(1) Szent István Egyetem, Kertészettudományi Kar, Növénytani Tanszék és Soroksári Botanikus Kert, H-1118 Budapest, Ménesi út 44.; Nagy.Jozsef@kertk.szie.hu

(2) MTA Ökológiai Kutatóközpont, GINOP Fenntartható Ökoszisztémák Csoport, H-8237 Tihany, Klebelsberg u. 3.

\section{Distribution of Pseudoleskea saviana (De Not.) Latzel in Hungary}

Abstract - Three new localities of the moss species Pseudoleskea saviana (De Not.) Latzel were discovered in the Börzsöny Mts in the administrative district of Perőcsény village, North Hungarian Mountains (Nagy-Hideg-hegy, near Hangyás-bérc, in the col between Csóványos and Magosfa). Small populations were found on shaded andesitic boulders in mixed deciduous forests. Up to the present, only old collections of the species were known from a single locality in the Mátra Mts; therefore, the red list status was data deficient. The morphological distinction of $P$. saviana from $P$. incurvata, its closely related congener also reported from Hungary is not always exempt from difficulties. However, the presence ( $P$. saviana) or absence ( $P$. incurvata) of a central strand in the stems, the shape of mid-leaf cells ( $P$. saviana: more elongated, 3-4 times as long as wide; $P$. incurvata: at most twice as long as wide), as well as the shape of the outer basal cells ( $P$. saviana: quadrate or shortly rectangular; $P$. incurvata: transversely elongated) seem to be reliable distinctive features.

Keywords: Leskeaceae, Lescuraea saviana, North Hungarian Montains, regionally threatened bryophyte in Europe, data deficient bryophyte in Hungary

Összefoglalás - Szerzők a Pseudoleskea saviana lombosmoha faj három új előfordulási adatát közlik a Börzsöny hegységből, Perőcsény község határából a Nagy-Hideg-hegy északi lejtőjéről, a Hangyás-bérc mellől, valamint a Csóványos - Magosfa nyeregből. A kis populációkat andezit görgetegen és törmeléken kialakult elegyes lomboserdő állományokban fedezték fel. Mostanáig csupán a faj egyetlen mátrai lelőhelyéről származó régi gyưjtései voltak ismertek, ezért a vörös listában adathiányos besorolással szerepel. A P. saviana és a Magyarországról szintén jelzett $P$. incurvata morfológiai elkülönítése atipikus példányok esetén nem mindig problémamentes. Megbízható elkülönítő bélyegeknek a szár központi nyalábjának megléte $(P$. saviana) vagy hiánya $(P$. incurvata), a levélközépsejtek alakja $(P$. saviana: 3-4szer hosszabb, mint széles; $P$. incurvata: max. 2-szer hosszabb, mint széles), valamint a levélalapi külső sejtek alakja ( $P$. saviana: jellemzően négyzetesen izodiametrikus; $P$. incurvata: keresztirányban megnyúlt) mondhatók.

Kulcsszavak: Leskeaceae, Lescuraea saviana, Észak-magyarországi-középhegység, Európában regionálisan veszélyeztetett mohafaj, Magyarországon adathiányos mohafaj

\section{Bevezetés}

A Börzsöny hegység mohavilága tekintetében hazai viszonylatban jól feldolgozott tájegységnek számít. Az 1950-60-as évek módszeres kutatásainak eredményeit VAJDA (1966) foglalta össze. Az utóbbi években a hegység területén folytatott mohatérképezés számos florisztikai 
újdonsággal szolgált. Ezek közül a Pseudoleskea saviana (De Not.) Latzel lombosmoha populációinak felfedezése az egyik legjelentősebb.

HoDGETTS (2015) szerint a Pseudoleskea és az általa elkülönítve tárgyalt Lescuraea nemzetség összesen kilenc faja fordul elő Európában. Közülük két közelrokon faj, a Pseudoleskea incurvata (Hedw.) E. Lawton és a Pseudoleskea saviana szerepel mohaflóránk aktuális nyilvántartásában (PAPP et al. 2010).

Rendszertani helyük

Mohák / Bryophyta törzs / Bryopsida osztály / Hypnales rend / Leskeaceae család / Pseudoleskea (Lescuraea) nemzetség

\section{Elterjedés}

A Pseudoleskea incurvata (syn. Lescuraea incurvata (Hedw.) E. Lawton) Európa nagy területein (Skandinávia, Közép-Európa, Mediterráneum, Balkán-félsziget, Kelet-Európa) (HoDGETTS 2015), továbbá Észak-Amerikában (SPENCE 2014) elterjedt boreális-montán taxon (DÜLL 1985).

A Pseudoleskea saviana (syn. Lescuraea saviana (De Not.) E. Lawton, Pseudoleskea illyrica Glowacki) kontinentális-szubalpin flóraelem (DÜLL 1985), amely a Balkán-félsziget országaiban általánosan elterjedt, gyakori a montán régióban (PAPP et al. 2016), de jelen van a Mediterrán térségben (Franciaország, Korzika, Olaszország), szórványosan Közép-Európában (Ausztria, Szlovákia), valamint Kelet-Európában Ukrajnában, a Krím-félszigeten és a Kaukázus európai részén is (HoDGETTS 2015). Ros et al. (2013) alapján Törökországban is előfordul, az iráni Elburz hegységből ZARE et al. (2011) közlik. Észak-Amerika nyugati részén szórványos előfordulású (SPENCE 2014).

\section{Hazai előfordulás}

Részben a taxon határozási nehézségei miatt a Pseudoleskea incurvata hazai előfordulásának megítélése igen ellentmondásos (ORBÁN \& VAJDA 1983, ERZBERGER \& PAPP 2004, ERZBERGGER 2009, PAPP et al. 2010). Egyetlen, igazolásra váró irodalmi adata ismert a Kőszegi-hegységből („im Langen Graben” Latzel 1930, Boros 1964, ORBÁN \& VAJDA 1983, PURGER et al. 1997). A faj Boros (1968) által a markazi Rókalyuktetőről (leg. M. Kovács, det. L. Vajda sub Lescuraea incurvata (Hedw.) Lawton var. incurvata), valamint a mátraházi Kecske-bérc sziklafaláról, Pseudoleskea atrovirens (Brid.) Schimp. var. patens Conradi \& I. Hagen név alatt említett előfordulásait a begyújtött herbáriumi példányok (BP 75667, BP 127617) revíziója alapján ERZBERGER \& PAPP (2004) cáfolta. Majd Erzberger egy a Kékes-tető északi lejtőjén (Parád) Boros által 1951. március 25-én gyűjtött Grimmia hartmanii Schimp. (BP 113128) példányban megtalálta kísérő fajként (ERZBERGER 2009). Azonban ez a $P$. incurvata példány (BP 177311) is később P. saviana-nak bizonyult Papp Beáta revíziója során (Papp 2016, ex litt.). A Pseudoleskea saviana-t az ország mai területén bizonyító herbáriumi példánnyal dokumentálva Boros Ádám gyűjtötte elsőként 1928. augusztus 5-én „In silvis septentr. montis Kékes prope Parád, ad saxa andesit, 800-1000 m" (BP 127616.). Ezt követően Boros 1930-ban és 1931-ben, Boros és Vajda 1951 során, majd Boros, Vajda, Pócs és Gelencsér 1952-ben gyüjtötte ugyanerről a területről. Hosszú szünet után Papp Beáta 2007. június 27-én találta a Kékes-tető északi lejtőjén, andezit sziklán (BP 174829). P. incurvata-nak határozta, majd később ezt a példányt P. saviana-ként revideálta (Papp 2016, ex litt.). Boros 1952. április 27-i gyűjtésének cédulája alapján a populáció pontos lelőhelye Parád község (Heves megye) határában, a Kékes-tetőn, erdővel borított andezitsziklákon, 950-1000 m magasságban található. „an bewaldeten Andesitfelsen des Berges Kékes bei Parád, 950-1000 m” (ERZBERGER \& PAPP 2004). Bizonyító példánya és duplumai az MTM Növénytárában lelhetők fel (BP 83964) . 


\section{Cönológiai karakter}

ORBÁn \& VAJDA (1983) szerint a Pseudoleskea incurvata Hypno-Polypodietum elem, míg hazai viszonylatban a Pseudoleskea saviana Acerion pseudoplatani cönológiai karakterét feltételezi.

Védettség, veszélyeztetettség

Mivel a Kékes-tető északi lejtőjén található Pseudoleskea populáció példányainak taxonómiai revíziójára csak 2016-ban került sor, az akkori ismeretek alapján PAPP et al. (2010) a Pseudoleskea incurvata-t még mint kipusztulással veszélyeztetett $\mathrm{CR}$ besorolású, míg a Pseudoleskea saviana-t adathiányos, DD-va besorolású fajként tartja számon. A Pseudoleskea saviana európai szinten regionálisan veszélyeztetett taxon (RT) (ECCB 1995), de DélkeletEurópában meglehetősen gyakori (PAPP et al. 2016). Magyarországon egyikük sem áll természetvédelmi oltalom alatt (ANONYM 2012).

\section{Anyag és módszer}

Magyarország mohaflórájának térképezése keretében a Magas-Börzsönyben a 8079/2 és 8079/4-es KEF kvadrátokban, a Nagy-Hideg-hegyen, valamint a Hangyás-bérc és a Magosfa térségében 2016 május-szeptemberi időszakban több alkalommal, valamint a Kékes-tetőn augusztus 12-én, a mátraházi Kecske-bércen november 25-én végeztünk terepi kutatást. A lelőhelyek koordinátáit GPS-készülékkel rögzítettük. A P. saviana taxon azonosításához LIMPRICHT (1895), LAWTON (1957), ORBÁN \& VAJDA (1983) és SPENCE (2014), határozókulcsait használtuk, a morfológiai leírásokhoz is ezeket a munkákat, továbbá saját megfigyeléseinket vettük alapul. A mohák megnevezésénél PAPP et al. (2010) munkáját, míg az edényes növények esetében KIRÁLY et al. (2009) határozókönyvét vettük alapul.

A begyújtött bizonyító herbáriumi példányokat a Magyar Természettudományi Múzeum Növénytárában (BP), valamint Nagy József, Németh Csaba és Peter Erzberger magánherbáriumaiban helyeztük el. A $P$. saviana és $P$. incurvata makro- és mikroszkópos bélyegeinek illusztrálására a HCsN 7955, illetve B-Erzberger 18339 azonosítószámú herbáriumi példányokat használtuk. Az összehasonlító vizsgálatokhoz összesen kilenc $P$. saviana és hat $P$. incurvata herbáriumi példányt használtunk fel (lásd alább).

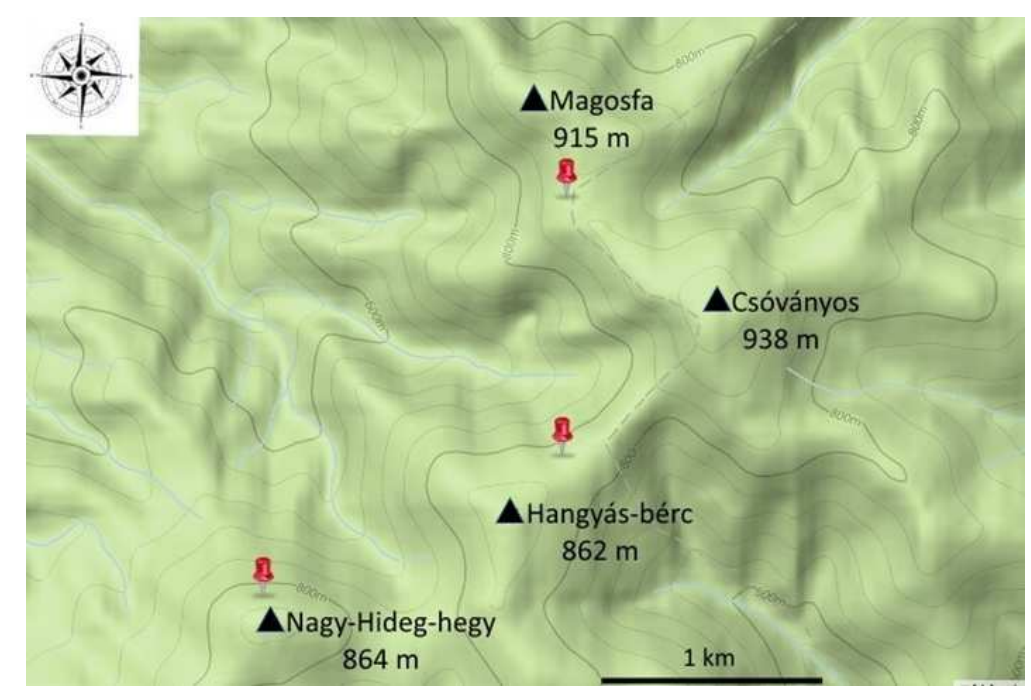

274
1. ábra. A P. saviana ismertté vált előfordulásai a Börzsöny hegységben Fig. 1. New occurrences of $P$. saviana in the Börzsöny Mts 


\section{Eredmények}

A Börzsöny hegységben a P. saviana három kicsi, de stabil állományát fedeztük fel (1. ábra), továbbá az egyetlen korábbi, a Mátrából ismert adatát is sikerült megerősíteni. Ezzel a faj ismert hazai előfordulásainak száma három KEF kvadrátban (2. ábra) összesen négyre emelkedett.

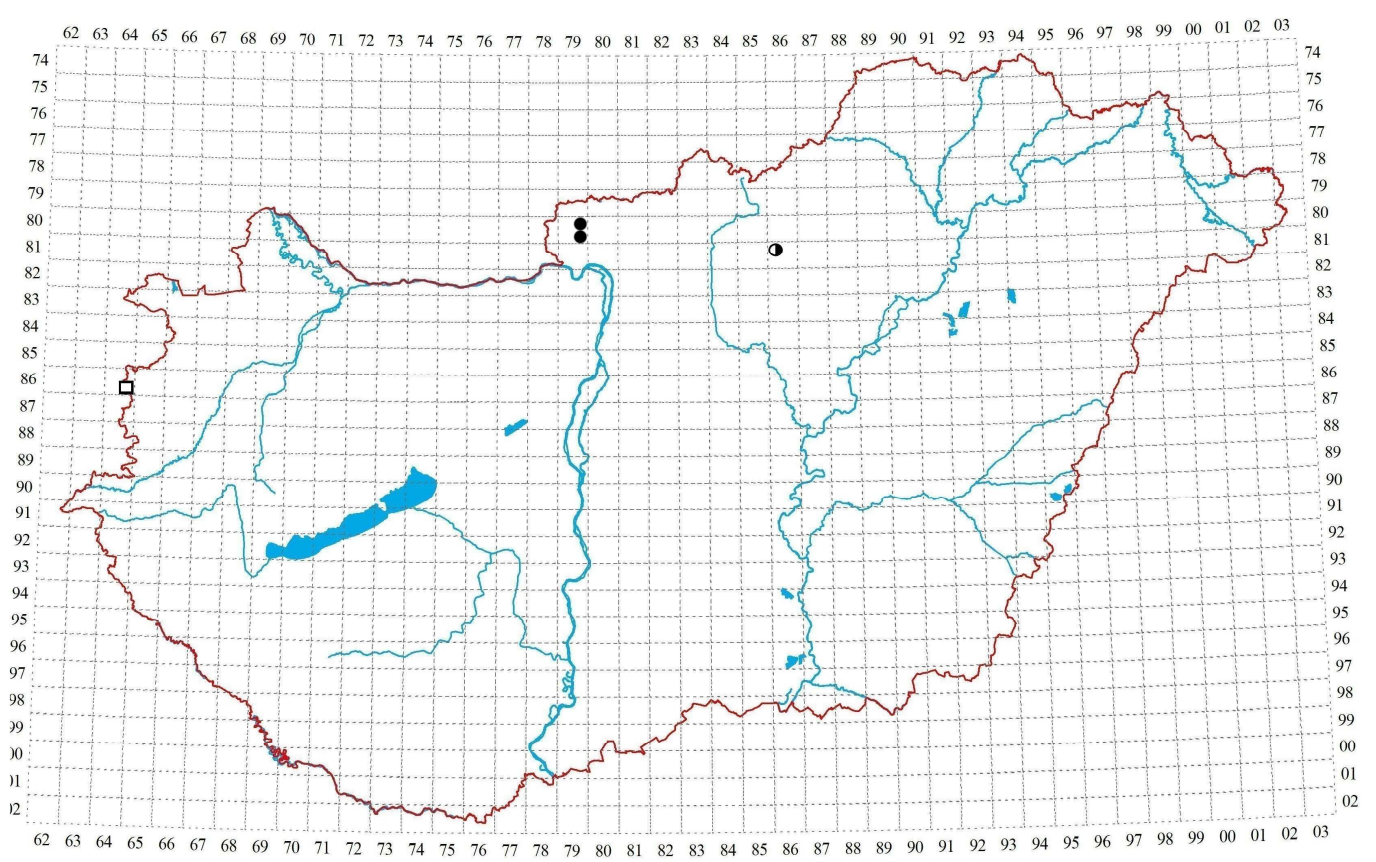

2. ábra. A P. saviana (•: új előfordulás, đ: régi előfordulás recens megerősítéssel) és $P$. incurvata ( $\square$ : régi előfordulás recens megerősítés nélkül) hazai előfordulásai

Fig. 2. Occurences of $P$. saviana ( $\bullet$ : new occurrence, $\mathbf{0}$ : old occurrence confirmed recently) and $P$. incurvata ( $\square$ : old occurrence without recent confirmation) in Hungary

\section{Börzsöny}

I. A Nagy-Hideg-hegyen 2016 májusában megtalált $P$. saviana mohapárnák száma eléri a húszat. A telepek mérete 40 és $800 \mathrm{~cm}^{2}$ között van. A párnák túlnyomó többsége a periglaciális törmeléklejtő kisebb-nagyobb szikladarabjain fordul elő (3. ábra). Egy esetben talajba ágyazódó magányos andezit sziklán, egy esetben pedig magas kőris talajból kiemelkedő gyökfőjén jelent meg. Sporofiton nem volt megfigyelhető.

Lelőhelyi adatok és élőhely jellemzés:

Pest megye; Perőcsény: Nagy-Hideg-hegy, KEF: 8079.4, N $47^{\circ}$ 56’ 14,5”, E $18^{\circ}$ 55’ 18,7”; (Perőcsény 32/E erdőrészlet, egy párna a 32/C erdőrészletben) északi kitettségben, tszf. 820850 m magasságban, 30-35 meredekségű, andezit kőgörgeteggel borított lejtőn, szurdokerdő jellegű erdőállományban. A párnák mintegy 0,2 ha területen elszórtan, kisebb csoportokban fordulnak elő. 


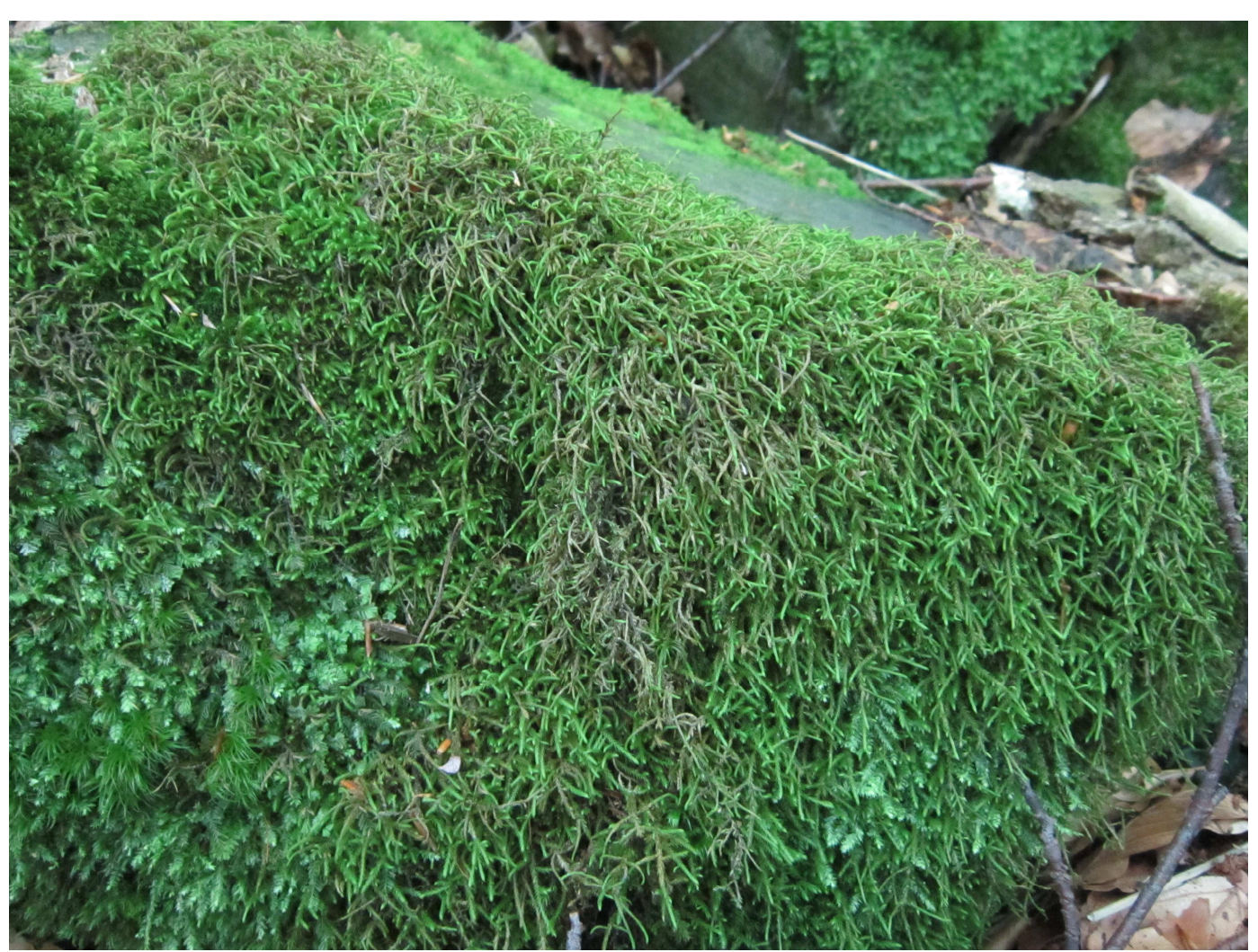

3. ábra. P. saviana nedves állapotban a Nagy-Hideg-hegy északi lejtőjén (Nagy J. felvétele)

Fig. 3. Moist P. saviana on the northern slope of Nagy-Hideg-hegy (photo by J. Nagy)

A Nagy-Hideg-hegy északi lejtőjének kőzettani képződményei Magasbörzsönyi és Dobogókői Andezit Formáció, kőzetösszetételét tekintve andezit és andezit piroklasztikum alkotja (GYALOG \& SíKHEGYI 2005).

A görgeteg szikladarabjainak felülete $20 \mathrm{~cm} \times 25 \mathrm{~cm}$-től, a $80 \mathrm{~cm} \times 90 \mathrm{~cm}$-ig terjedő mérettartományban oszlik meg. Az enyhébb lejtésű blokkokon sekély humuszréteg alakult ki.

A görgeteggel borított termőhelyen a lombkoronaszintet alkotó fafajok: Acer pseudoplatanus, Fraxinus excelsior, Acer platanoides, Tilia platyphyllos, szálanként Ulmus glabra, a törmeléklejtő szélein Fagus sylvatica. A domináns fafajok lombja nitrogénben gazdag, lehulló leveleik gyorsan lebomlók. A cserjeszintben elszórtan Ribes uva-crispa fordul elő. A gyér gyepszintben szálanként Impatiens noli-tangere van jelen, de a görgetegen és annak szélein megjelenik a Galium odoratum, Geranium robertianum és Dryopteris filix-mas is. A törmeléklejtő mohaszintje igen fejlett, becsült borítása eléri a 70\%-ot (4. ábra).

A termőhely mikroklímája hűvös-párás, erősen árnyalt, fényszegény, az év meghatározó időszakában csak szórt fény éri. Május-július folyamán a lombkorona lékjeinek köszönhetően rövid ideig, 11-12 óra között közvetlen megvilágítást is kap. A termőhely az északias irányból fújó szeleknek kitett. A növényi indikáció alapján vízellátottság tekintetében üdemérsékelten nedves termőhelynek tekinthető.

A részletesen felvételezett $P$. saviana előfordulás (5. ábra) egy $\mathrm{kb} .50 \mathrm{~cm} \times 65 \mathrm{~cm}$ felületű, $5^{\circ}$ lejtésű szikladarab közel $20 \mathrm{~cm} \times 40 \mathrm{~cm}$-es részletét borítja. A homogén mohapárna a szikladarab élén aláhajlik. Ugyanezen a blokkon megtelepedett társuló mohafajok borítása: Brachythecium geheebii $\left(1200 \mathrm{~cm}^{2}\right)$, Dicranum scoparium $\left(25 \mathrm{~cm}^{2}\right)$, Grimmia hartmanii $(100$ $\left.\mathrm{cm}^{2}\right)$, Metzgeria furcata $\left(30 \mathrm{~cm}^{2}\right)$, Plagiochila porelloides $\left(100 \mathrm{~cm}^{2}\right)$. 
NAGY \& NÉMETH (2017): A Pseudoleskea saviana Magyarországon

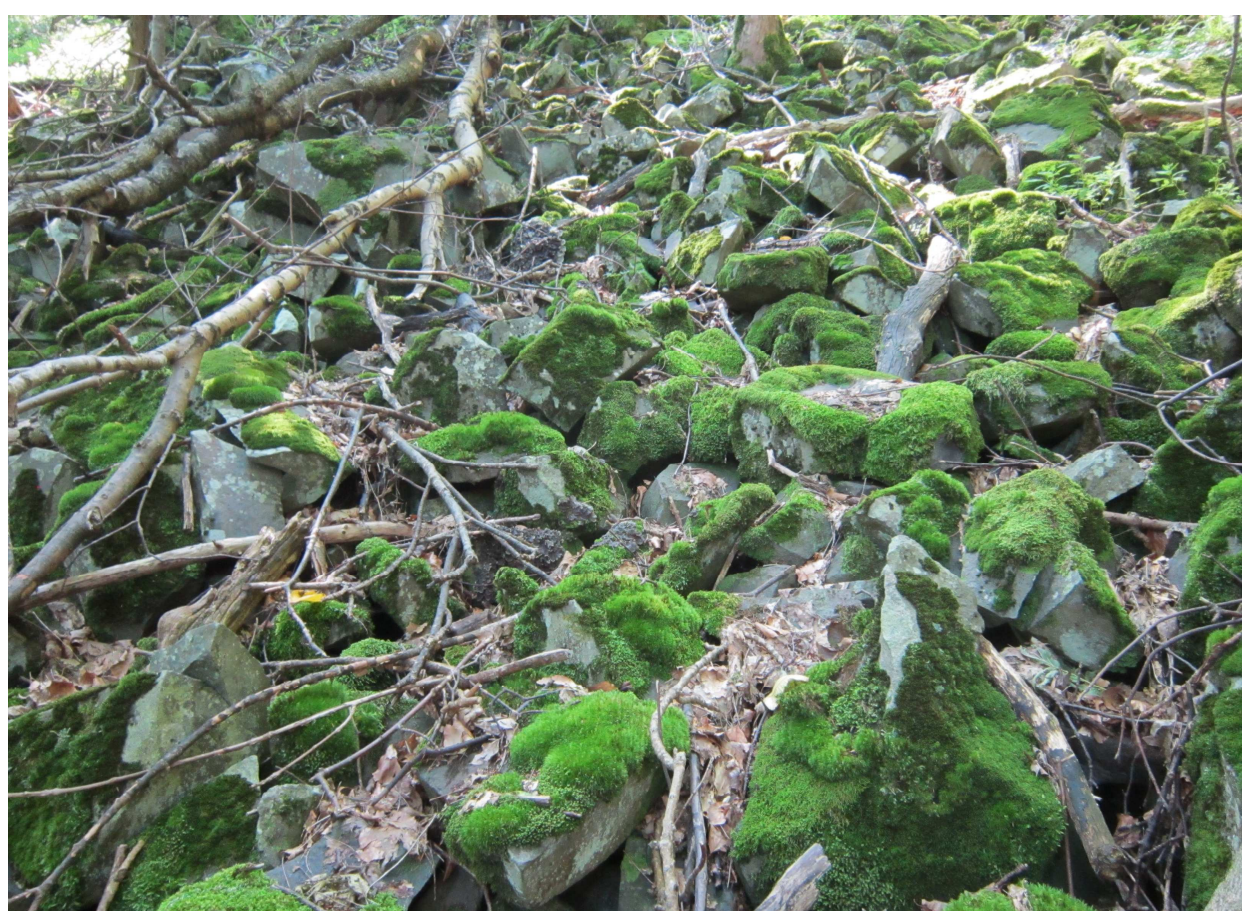

4. ábra. Mohapárnákkal borított sziklagörgeteg a Nagy-Hideg-hegy északi lejtőjén (Nagy J. felvétele) Fig. 4. Andesite boulders covered with various bryophytes on the northern slope of Nagy-Hideg-hegy (photo by J. Nagy)

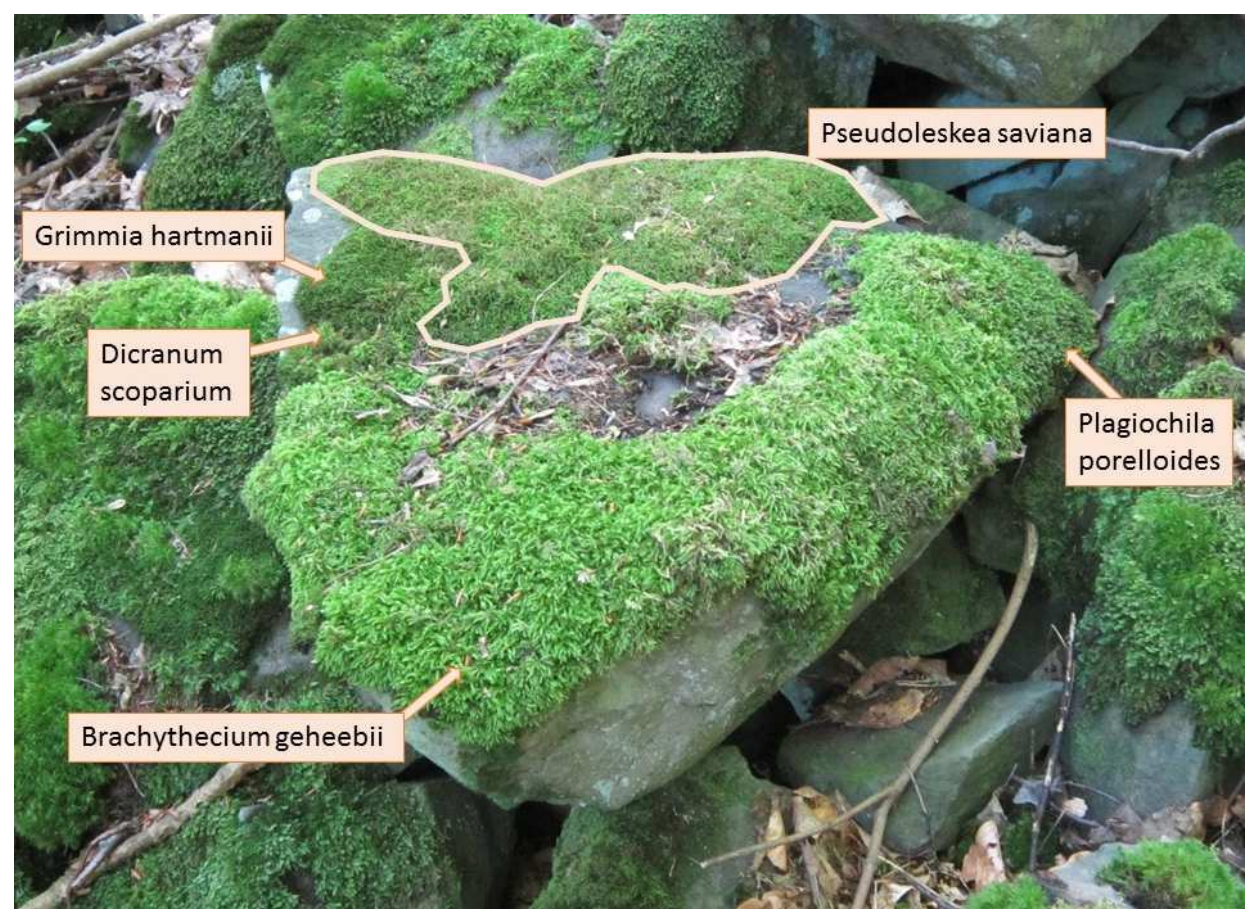

5. ábra. P. saviana és a vele társuló mohafajok a Nagy-Hideg-hegy északi lejtőén (Nagy J. felvétele) Fig. 5. P. saviana and associated bryophytes on the northern slope of Nagy-Hideg-hegy (photo by J. Nagy) 
A környező, 1 méteres sugarú körben található sziklatörmeléken előforduló további mohafajok: Brachythecium populeum, Homalothecium sericeum, Hypnum cupressiforme, Isothecium alopecuroides, Jamesoniella autumnalis, Plagiothecium cavifolium, P. denticulatum, Pterigynandrum filiforme.

A herbáriumi példányok gyűjtésének időpontjai 2016. 05. 23., 2016. 06. 18., 2016. 07. 30., 2016. 08. 20. leg. Nagy J., det.: Németh Cs. [HCsN 7955], conf.: P. Erzberger.

II. A Hangyás-bérc oldalában, a Katalin-szikla közelében 2016 szeptemberében megtalált $P$. saviana mohapárnák száma tíz. Méretük 70 és $600 \mathrm{~cm}^{2}$ közötti. A párnák andezit törmeléken és laposabb, talajba ágyazódó szikladarabokon, egymás közelében, két csoportban, 10, illetve $1 \mathrm{~m}^{2}$ területen, koncentráltan fordulnak elő. Sporofiton nem volt megfigyelhető.

Lelőhelyi adatok és élőhely jellemzés:

Pest megye; Perőcsény: Hangyás-bérc mellett, KEF: 8079.4, N 47 56’ 35,8”, E $18^{\circ}$ 56’ 24,4”; (Perőcsény 45/C erdőrészlet). A termőhely északi kitettségben, tszf. 820-830 m magasságban, $20-25^{\circ}$ meredekségű, erdővel borított törmelékes talajú lejtőn található.

Kőzettani képződményei Magasbörzsönyi és Dobogókői Andezit Formáció, kőzetösszetételét tekintve andezit és andezit piroklasztikum (GYALOG \& SíKHEGYI 2005).

A sziklatörmelék moha által preferált darabjainak felülete $10 \mathrm{~cm} \times 20 \mathrm{~cm}$-től, a $60 \mathrm{~cm} \times$ $70 \mathrm{~cm}$-ig terjedő mérettartományban oszlik meg. A közeli, 6-10 méter átmérőjű sziklatömbökön a P. saviana nem volt megfigyelhető.

A törmelékkel borított termőhelyen a lombkoronaszintet alkotó fafajok: Fagus sylvatica és Fraxinus excelsior. A cserje és gyepszint hiányzik. A törmeléken a mohaszint kevéssé fejlett. A P. saviana többségében homogén párnákat alkot. Társuló mohafajok: Grimmia hartmanii, Hypnum cupressiforme, Pterigynandrum filiforme.

A termőhely erősen árnyalt, fényszegény, az év meghatározó részében csak szórt fény éri. Az északias irányból fújó szeleknek kitett, vízellátottsága alapján mérsékelten üdemérsékelten száraz termőhely.

A herbáriumi példányok gyűjtésének időpontja 2016. 09. 24., leg. et det. Nagy J., conf.: Németh Cs. [HCsN 8038], és P. Erzberger.

III. A Csóványos és Magosfa nyergében 2016 szeptemberében felfedezett $P$. saviana mohapárnák száma 24. Méretük 50 és $1000 \mathrm{~cm}^{2}$ közötti. A párnák törmeléken és laposabb, talajba ágyazódó szikladarabokon, egymás közelében elhelyezkedő két csoportban fordulnak elő 1,5 illetve $2 \mathrm{~m}^{2}$ területen. Sporofiton nem volt megfigyelhető.

Lelőhelyi adatok és élőhely jellemzés:

Pest megye; Perőcsény: Csóványos és Magosfa nyerge, KEF: 8079.2, N 47 57’ 13,2”, E $18^{\circ} 56^{\prime}$ 25,4"; (Perőcsény 43/B erdőrészlet. A termőhely 880 m tszf. magasságban, nyugatias kitettségben, egy sziklafal erdővel borított törmelékszoknyájának alsó peremén, $10-15^{\circ}$ meredekségű lejtőn található.

Kőzettani képződménye Magasbörzsönyi Andezit Formáció, kőzetösszetételét tekintve andezit (GYALOG \& SíKHEGYI 2005).

A sziklatörmelék moha által preferált darabjainak felülete $10 \mathrm{~cm} \times 20 \mathrm{~cm}$-től a $60 \mathrm{~cm} \times 70$ cm-ig terjedő mérettartományban oszlik meg. Durvább törmeléken a $P$. saviana nem volt megfigyelhető.

A lombkoronaszintet alkotó domináns fafaj a Fraxinus excelsior, amihez szálanként Fagus sylvatica és Acer pseudoplatanus elegyedik. A cserjeszint hiányzik, a gyepszintben elszórtan 
Geranium robertianum, valamint Fraxinus excelsior magoncok vannak jelen. A görgeteg mohaszintje fejlett.

A P. saviana túlnyomóan homogén párnákat alkot. A környező sziklatörmeléken megfigyelt mohafajok: Brachythecium populeum, Bryum moravicum, Dicranum scoparium, Grimmia hartmanii, Hypnum cupressiforme, Isothecium alopecuroides, Metzgeria furcata, Paraleucobryum longifolium, Plagiochila porelloides, Pseudoleskeella nervosa, Pterigynandrum filiforme, Tortula ruralis.

A termőhely a magas kőris uralta lombkoronaszintnek köszönhetően szórt fénnyel közepesen ellátott. Az északias irányból fújó szeleknek kevésbé kitett, vízellátottsága alapján mérsékelten üde-mérsékelten száraz.

A herbáriumi példányok gyűjtésének időpontja 2016. 09. 24., leg. et det. Nagy J., conf.: Németh Cs. [HCsN 8312, 8313], és P. Erzberger.

\section{Mátra}

Az ismert Kékes-tetői állomány célzott keresésére Dr. Papp Beátával közösen 2016. augusztus 12-én került sor. Ennek során a Kékes-tető csúcsától északra, a kilátótorony és a sífutóút közti, idős, Galium odoratum típusú üde montán bükkös állományban (6. ábra) leltük fel a $P$. saviana párnáit, a Boros-féle gyújtés 950-1000 m-es magassági adatának megfelelően. Az erdőrészlet állománybelsőjét a szórt és közvetlen napfény mozaikossága jellemzi.

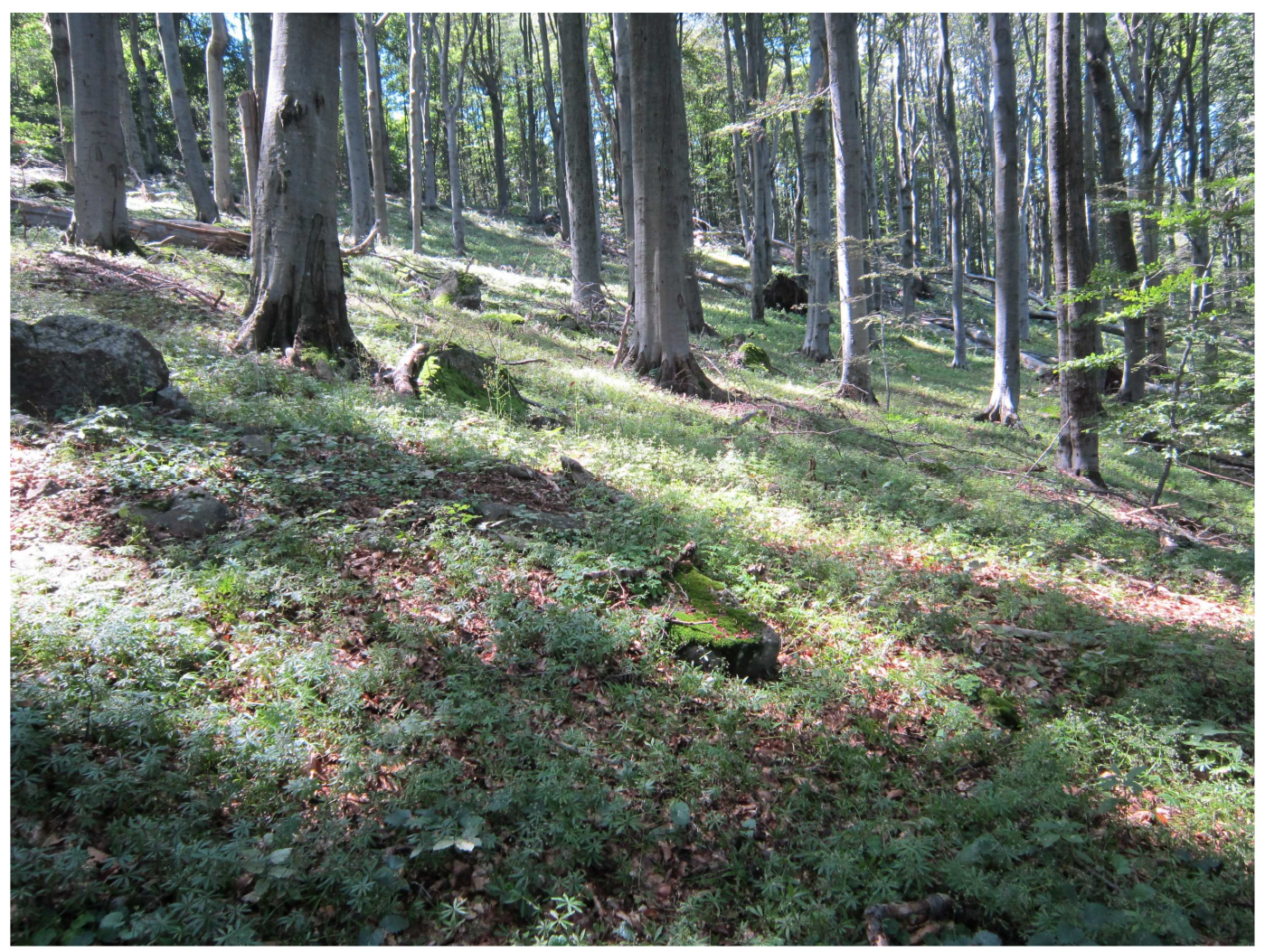

6. ábra. A P. saviana termőhelye a Kékes-tető északi lejtőjének idős bükkösében (Nagy J. felvétele)

Fig. 6. Habitat of $P$. saviana in old growth beech forest on the northern slope of Mt. Kékes (photo by J. Nagy) 
Mintegy fél hektárnyi erdőterület bejárása során a megtalált mohapárnák száma meghaladta a tizenötöt. Jellemzően az elszórtan elhelyezkedő, mélyen talajba ágyazódó, lapos, enyhe lejtésű szikladarabokon (7. ábra), valamint egy esetben (Parád 26/E erdőrészlet) törmeléklejtőn fordultak elő. Ugyanakkor hiányoztak a hirtelen kiemelkedő, meredek oldalú sziklatömbökről.

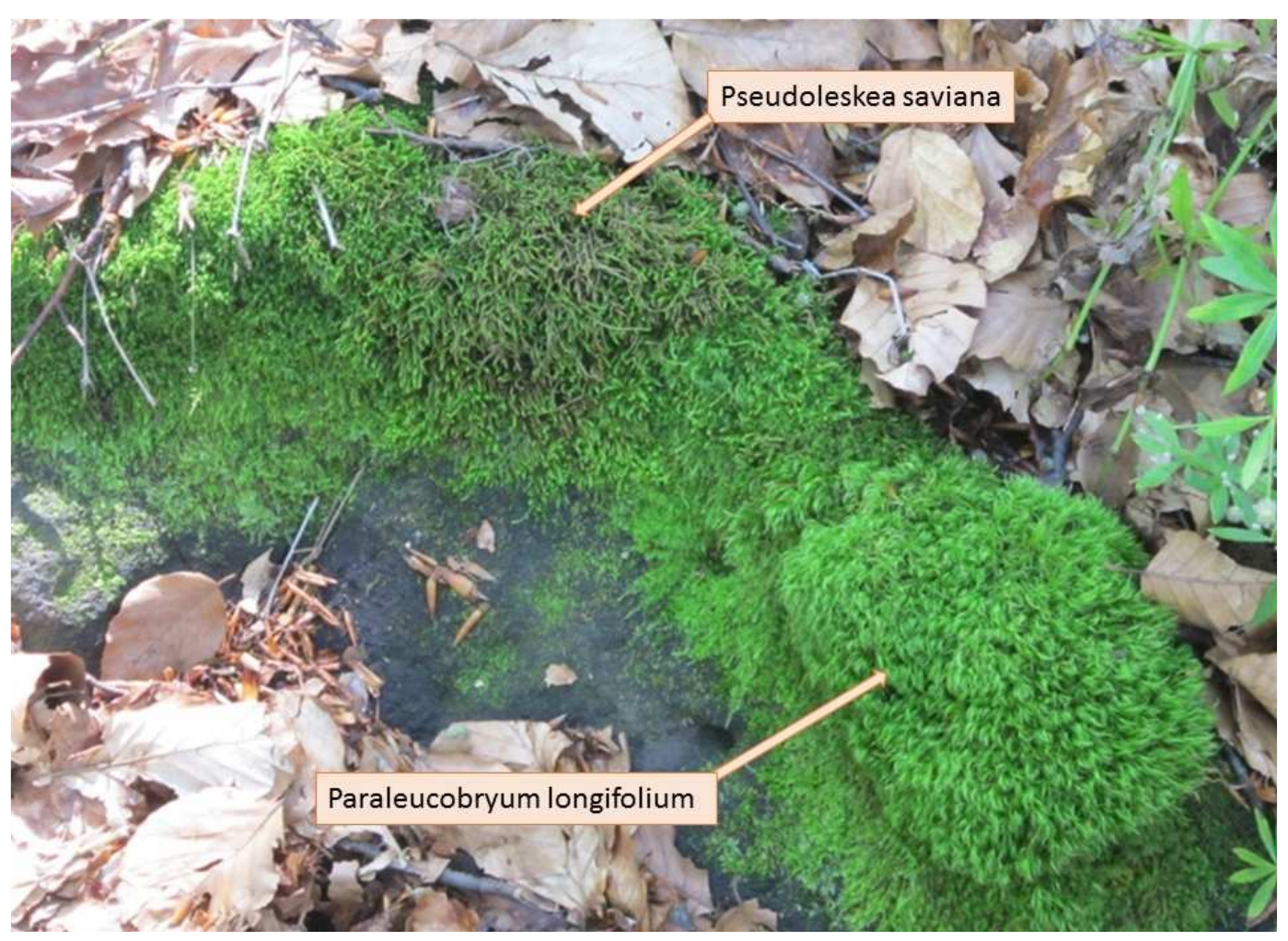

7. ábra. Kékes-tető, P. saviana talajba ágyazódó sziklán Paraleucobryum longifolium-mal társulva (Nagy J. felvétele)

Fig. 7. P. saviana accompanied by Paraleucobryum longifolium in its typical habitat on Mt. Kékes (photo by J. Nagy)

A részletesen jellemzett $P$. saviana előfordulás egy kb. $80 \mathrm{~cm} \times 50 \mathrm{~cm}$ felületű, lapos, enyhe lejtésű szikladarab $25 \mathrm{~cm} \times 20 \mathrm{~cm}$-es részét borítja. Párnája homogén. Társuló mohafajok a Brachythecium populeum, Dicranum scoparium, Grimmia hartmanii, Pterigynandrum filiforme. Néhány sziklán kizárólag P. saviana volt megfigyelhető. Sporofitont itt sem találtunk.

Lelőhelyi adatok és élőhely jellemzés:

Heves megye; Parád: Kékes-tető, KEF: 8186.1, N $47^{\circ}$ 52’ 23,4”, E 2000' 39,9”; (Parád 29/J erdőrészlet), északi kitettségben, tszf. 950-990 m tszf. magasságban, 20-25 meredekségü lejtőn.

A területre jellemző kőzettani képződmény a Kékesi Andezit Formáció, kőzetösszetételét tekintve piroxénandezit láva, alárendelten lávabreccsa (GYALOG \& SíKHEGYI 2005).

A herbáriumi példányok gyűjtésének időpontja 2016. 08. 12., leg. et det. Nagy J. és Papp B. [HCsN 8498, BP 191585]. 


\section{A $P$. saviana és $P$. incurvata rövid morfológiai jellemzése és elkülönítési nehézségei}

P. saviana: Erőteljes növény. Gyepje sötétzöld, barnászöld, sűrű. Szára hosszú, elterülő, sok parafilliummal rendelkező, kissé szabálytalanul, fésűsen elágazó. Szár- és ágvégei kampósak (8.a ábra). A szár néhány apró sejtből álló központi nyalábot tartalmaz (9.a ábra).
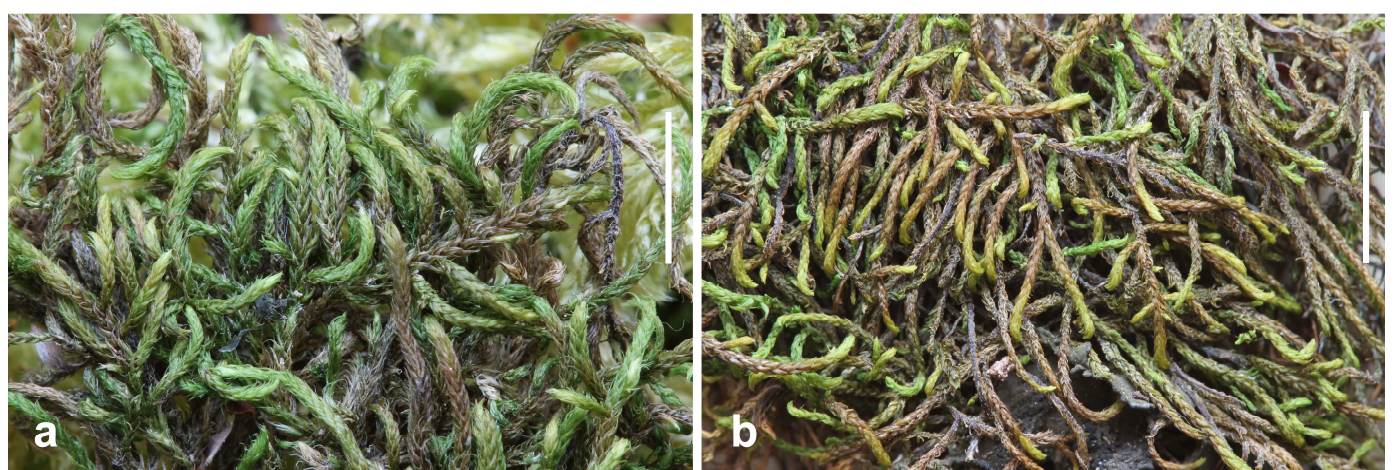

8. ábra. A P. saviana (a) és P. incurvata (b) habitusfotója (méretvonal: $5 \mathrm{~mm}$ ) (Németh Cs. felvételei)

Fig. 8. Habit of $P$. saviana (a) and P. incurvata (b) (scale bar: $5 \mathrm{~mm}$ ) (photos by Cs. Németh)
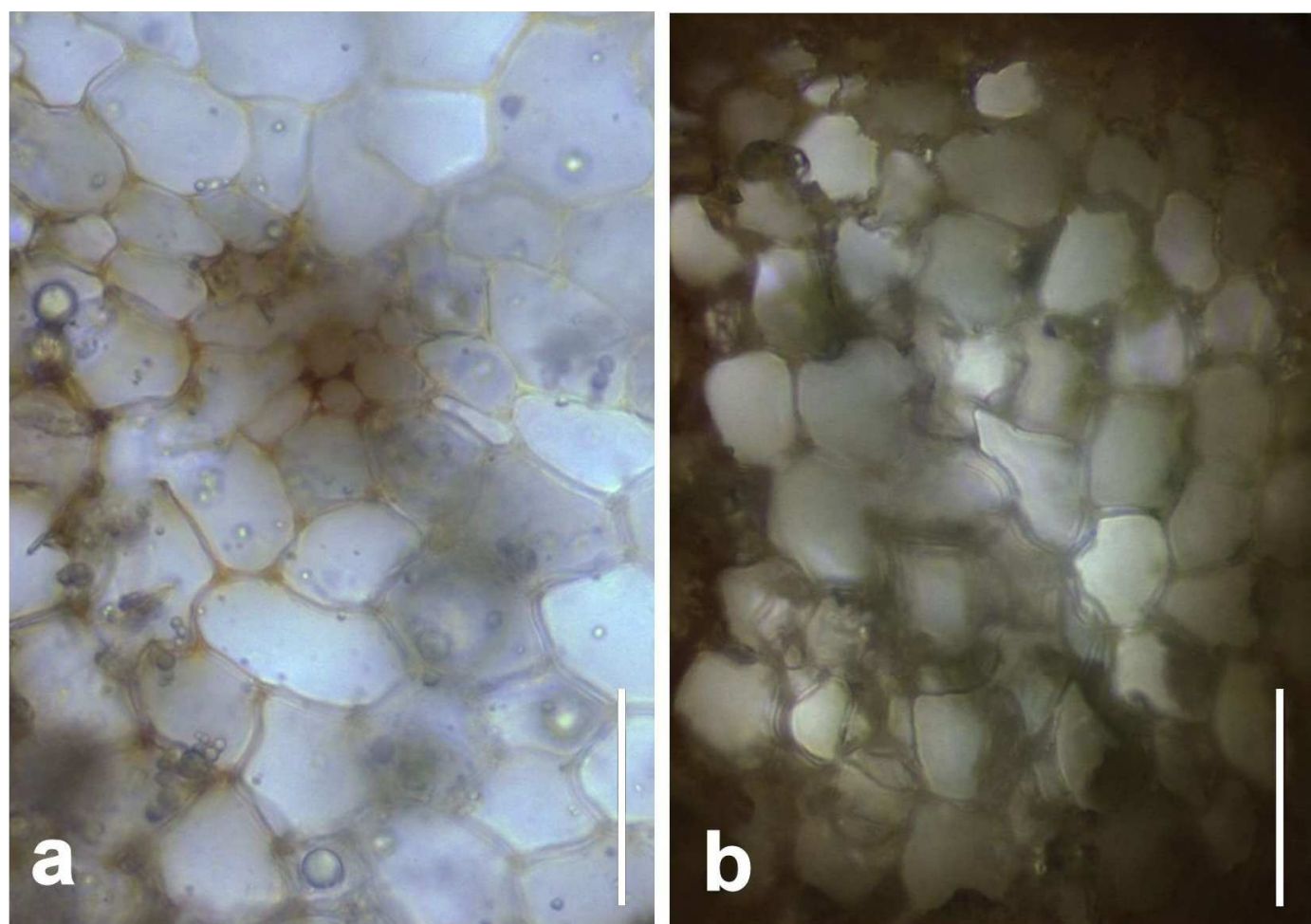

9. ábra. A P. saviana (a) és P. incurvata (b) szárkeresztmetszete (méretvonal: $50 \mu \mathrm{m}$ ) (Németh Cs. felvételei)

Fig. 9. Cross section of stems of $P$. saviana (a) and P. incurvata (b) (scale bar: $50 \mu \mathrm{m}$ ) (photos by Cs. Németh) 


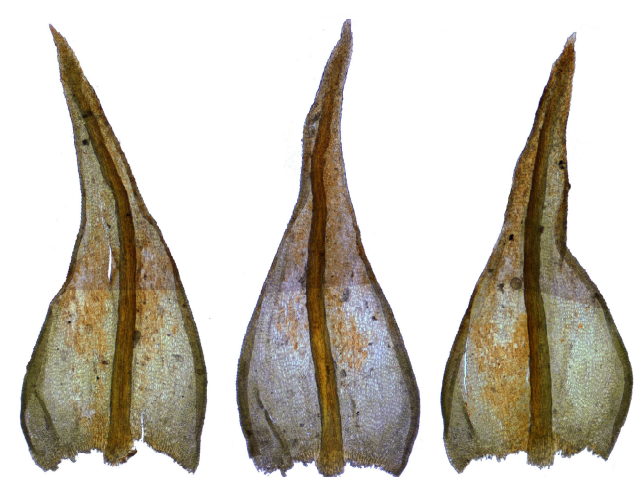

a
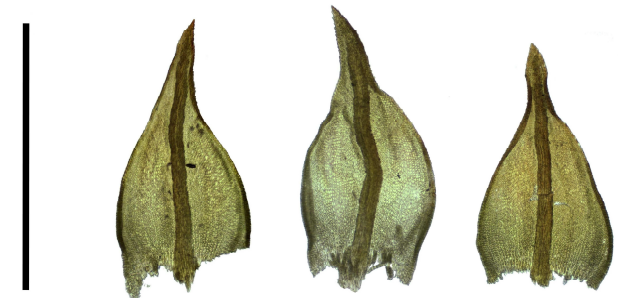

b

10. ábra. A P. saviana (a) és P. incurvata (b) szárlevelei (méretvonal: $1 \mathrm{~mm}$ ) (Németh Cs. felvételei) Fig. 10. Stem leaves of $P$. saviana (a) and $P$. incurvata (b) (scale bar: $1 \mathrm{~mm}$ ) (photos by Cs. Németh)
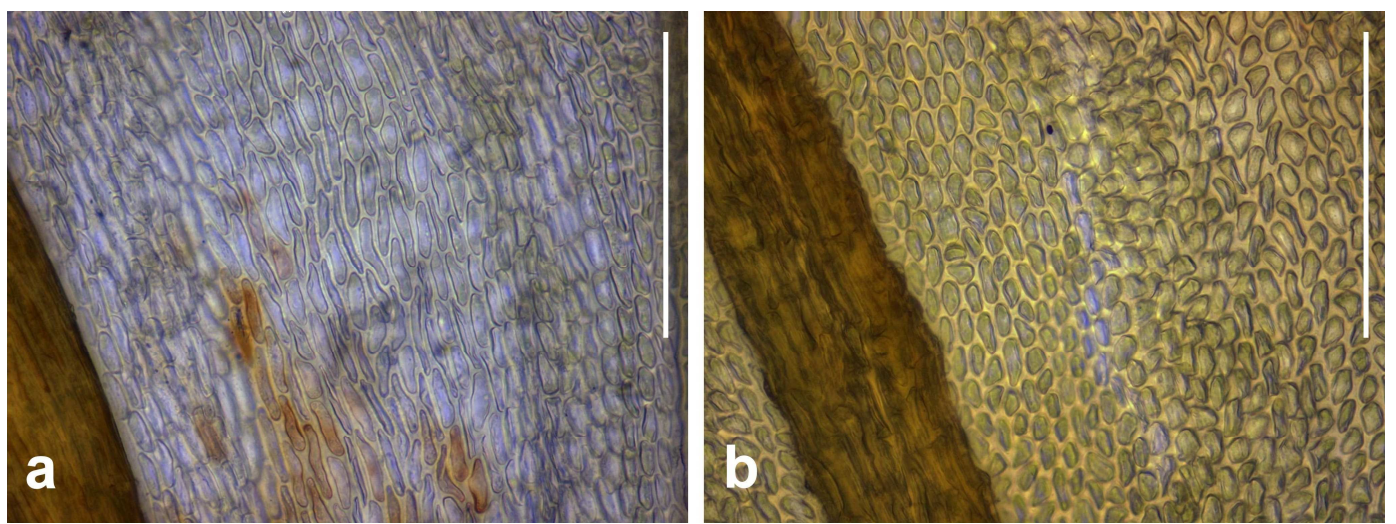

11. ábra. A P. saviana (a) és P. incurvata (b) levélközép sejtjei (méretvonal: $100 \mu \mathrm{m}$ ) (Németh Cs. felvételei) Fig. 11. Mid leaf cells of P. saviana (a) and P. incurvata (b) (scale bar: $100 \mu \mathrm{m}$ ) (photos by Cs. Németh)
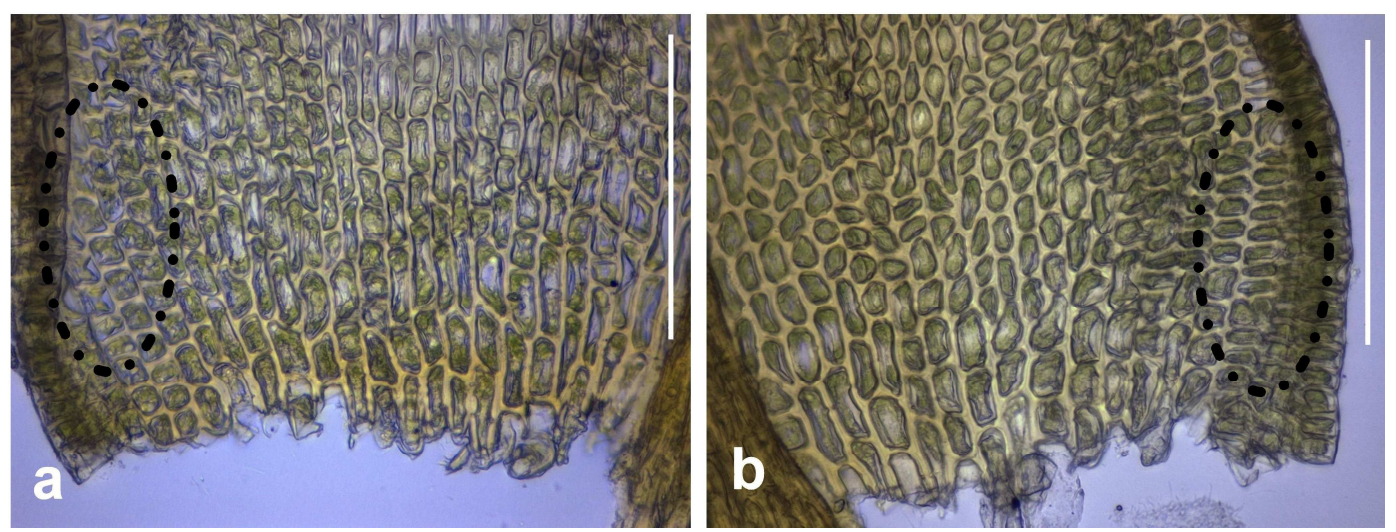

12. ábra. A P. saviana (a) és $P$. incurvata (b) levélalapi része a jellegzetesen izodiametrikus, illetve keresztirányban megnyúlt szélső sejtekkel (méretvonal: $100 \mu \mathrm{m}$ ) (Németh Cs. felvételei)

Fig. 12. Basal part of the leaves of $P$. saviana (a) and P. incurvata (b) highlighting the characteristic isodiametric and transversely elongated submarginal cells, respectively (scale bar: $100 \mu \mathrm{m}$ ) (photos by Cs. Németh) 
Levelei tojásdad lándzsásak, hosszan kihegyesedők, kissé hajlottak, aszimmetrikusak, redősek, lefutók, hosszú, kissé fogas csúcsukon részben kilépő érrel. A levelek széle végig begöngyölt (10.a ábra). A sejtek a levél közepén 20-35 mikrométeresek, megnyúltak (11.a ábra). A saroksejtek négyzetesen izodiametrikusak (12.a ábra). A tok barna nyélen tojásdad lándzsás, kissé oldalt hajló.

P. incurvata: Kisebb növény. Gyepje merev, kemény, szőrszerűen kiterülő, sárgászöld, rozsdabarna. Szára hosszú, elfekvő, szabálytalanul elágazó, sok parafilliummal rendelkező. A szár- és ágvégek erősen görbültek (8.b ábra). A szár központi nyalábot nem tartalmaz (9.b ábra).

Levele széles tojásdad alapból röviden kihegyesedő, kissé hajlott, aszimmetrikus, homorú, alsó felében hosszredős, széle a tőnél visszahajló. Ere erős, a csúcs előtt végződik (10.b ábra). A sejtek a levél közepén 12-20 mikrométeresek, vastag falúak, változatos alakúak, közéjük rövidebbek is keveredhetnek (11.b ábra). A saroksejtek részben keresztben hosszúkásak, részben négyzetesek (12.b ábra).

A két faj mikromorfológiai bélyegek tekintetében meglehetősen nagy hasonlóságot mutat, elkülönítésük nehézségeire a nemzetközi szakirodalomban található ellentmondások is rámutatnak. A szár központi kötegének meglétére/hiányára nem minden forrásmunka tér ki (pl. LAWTON 1957, 1971). A P. incurvata központi kötege hiányzik LiMPRichT (1895), MAIER (ms.), Nebel \& Schoepe (2001), Cortini Pedrotti 2005, Brugués \& Ruiz (2016), megvan SPENCE (2014) szerint. Az általunk vizsgált P. incurvata példányok: B-Erzberger 18339 (Albánia, leg. P. Erzberger); BP 182676 (Görögország, leg. Papp B.); BP 188710 (Macedónia, leg. Papp B.); BP 179001 (Montenegró, leg. Papp B.); BP 168271, BP 173248 (Szerbia, leg. Papp B.) nem tartalmaztak centrális köteget, míg valamennyi vizsgált hazai és külföldi $P$. saviana gyüjtés: HCsN 7955, 8038, 8312, 8313 (Börzsöny, leg. Nagy J.); HCsN 8498 (Mátra, leg. Nagy J.); B-Erzberger 18338 (Albánia, leg. P. Erzberger); BP 191584 (Görögország, leg. Papp B.); HCsN 8748, 8749 (Románia, leg. Ódor P.) kisebb sejtekből felépülő központi nyalábbal volt jellemezhető. Megjegyzendő, hogy CORTINI PEDROTTi (2005) a P. saviana esetében is a központi köteg hiányáról tudósít.

Ami általánosan elmondható a két faj közötti különbségekről, hogy a P. saviana termetesebb növény, mint a $P$. incurvata (8. ábra), előbbi faj szára tapasztalataink alapján kisebb-nagyobb kifejlettségben, de központi nyalábot tartalmaz, utóbbiból ez hiányzik (9. ábra). A P. saviana levelei nagyobb méretűek, hosszabb levélcsúccsal, levélközépsejtjei megnyúltabbak, 3-4-szer hosszabbak, mint szélesek, ellentétben a rövidebb levélcsúcsú, izodiametrikus vagy legfeljebb 2-szer olyan hosszú, mint széles, tömzsibb levélközép sejtekből álló $P$. incurvata levelekkel (10-11. ábra). A levél alapjának külső sejtjei a $P$. saviana esetében jellemzően négyzetesen izodiametrikusak, míg a $P$. incurvata esetében keresztirányban megnyúltak (12.ábra).

\section{Következtetések}

A korábban kizárólag a Mátra egyetlen pontjáról ismert $P$. saviana három új, stabil populációját fedeztük fel a Börzsöny hegységben, emellett célzott keresés eredményként igazoltuk a kékes-tetői populáció létezését is.

A P. incurvata Boros (1968), majd ORBÁn \& VAJDA (1983) által közölt, de téves határozáson alapuló (ERZBERGER \& PAPP 2004) előfordulási adatának igazolására 2016. november 25én a mátraházi Kecske-bércen tett bejárás eredménytelenül zárult. A Kékes-tetőn 2016. augusztus 12-én gyűjtött példányok vizsgálata, valamint az ugyaninnen származó korábbi herbáriumi gyűjtések Papp Beáta által elvégzett ismételt revíziója a $P$. incurvata mátrai előfordulását egyaránt cáfolja. Ugyanakkor a faj Kőszegi-hegységi (LATZEL 1930) előfordulásáról 
herbáriumi példány nem ismert, ottani és ezzel együtt magyarországi előfordulása továbbra is megerősítésre vár.

További $P$. saviana állományok keresésének elsősorban a Magas-Börzsöny és a Mátra 750-800 méter feletti montán régiójában lehet eredménye. A négy igazolt populáció alapján a faj hazai adathiányos (DD-va) (PAPP et al. 2010) besorolását javasoljuk veszélyeztetett (EN endangered) besorolásra változtatni a következő magyarországi moha vörös listában.

A börzsönyi állományok élőhelyei a faj cönológiai karakterének Acerion pseudoplatani jellegét támasztják alá, ugyanakkor a mátrai állomány Fagion jellegről árulkodik.

\section{Köszönetnyilvánítás}

Köszönettel tartozunk Peter Erzbergernek az irodalmazásban nyújtott segítségéért, a kézirathoz füzött értékes észrevételeiért, valamint az általa gyüjtött $P$. incurvata és $P$. saviana összehasonlító példányok rendelkezésünkre bocsátásáért. Külön köszönet illeti Dr. Papp Beátát az MTM Növénytárának mohagyüjteményébe történő betekintés, adatgyüjtés és a herbáriumi példányok vizsgálatának lehetővé tételéért, a kékestetői $P$. saviana populáció felkereséséhez és taxonómiai helyzetének tisztázásához nyújtott segítségéért, valamint rendkívüli alapossággal végzett lektori munkájáért. Köszönjük továbbá Ódor Péternek, hogy az általa Romániában gyűjiött $P$. saviana példányok vizsgálatát lehetővé tette számunkra. A mátraházi Kecske-bérc bejárásában való közremúködésért Magos Gábornak, a Mátrai TK természetvédelmi őrének tartozunk hálával. A $P$. incurvata kőszegi-hegységi aktuális előfordulásával kapcsolatban Peter Erzberger és Baráth Kornél 2016-ban végzett terepi kutatásainak eredményeire támaszkodtunk.

\section{Irodalomjegyzék}

ANonym (2012): A vidékfejlesztési miniszter 100/2012. (IX. 28.) VM rendelete a védett és a fokozottan védett növény- és állatfajokról, a fokozottan védett barlangok köréről, valamint az Európai Közösségben természetvédelmi szempontból jelentős növény- és állatfajok közzétételéről szóló 13/2001. (V. 9.) KöM rendelet és a növényvédelmi tevékenységről szóló 43/2010. (IV. 23.) FVM rendelet módosításáról [ministerial order concerning protection of nature]. - Magyar Közlöny 128: 20903-21019.

Boros Á. (1964): Bryophyta - Mohák. In: Soó R.: A magyar flóra és vegetáció rendszertani növényföldrajzi kézikönyve I. - Akadémiai Kiadó, Budapest, pp. 353-510.

Boros Á. (1968): Bryogeographie und Bryoflora Ungarns. - Akadémiai Kiadó, Budapest, 466 pp.

BRuguÉs M. \& RuIz E. (2016): Thuidiaceae. In: GuERRA J. \& BruguÉs M. (eds), Flora Briofitica Ibérica, Vol. VI, Hypnales: Fabroniaceae, Leskeaceae, Pterigynandraceae, Thuidiaceae. - Murcia, Universidad de Murcia, Sociedad Española de Briología, pp. 11-27.

CoRtini Pedrotti C. (2005): Flora dei muschi d'Italia. - Antonio Delfino Editore, Roma, pp. 890-895.

DüLL R. (1985): Distribution of the European and Macaronesian mosses (Bryophytina) II. - Bryologische Beiträge 5: 110-232.

ECCB (1995): Red data book of European bryophytes. - European Committee for Conservationof Bryophytes, Trondheim, $291 \mathrm{pp}$.

ERZBERGER P. (2009): Pseudoleskea incurvata (Hedw.) Loeske, Racomitrium aciculare (Hedw.) Brid. [Hungary]. In: BLOCKEEL T. L. (ed.), New national and regional bryophyte records, 20. - Journal of Bryology 31: 57.

ERZBERGER P. \& PAPP B. (2004): Annotated checklist of Hungarian bryophytes. - Studia Botanica Hungarica 35: 91-149.

GYALOG L. \& SíkHEGYI F. (sorozatszerk.) (2005): Magyarország földtani térképe, M=1:100 000. - A Magyar Állami Földtani Intézet kiadványa, Budapest. https://map.mfgi.hu/fdt100/ 
HoDGETTS N. G. (2015): Checklist and country status of European bryophytes - towards a new Red List for Europe. - Irish Wildlife Manuals, No. 84. National Parks and Wildlife Service, Department of Arts, Heritage and the Gaeltacht, Ireland.

KIRÁLY G. (szerk.) (2009): Új magyar füvészkönyv. Magyarország hajtásos növényei. Határozókulcsok. ANPI, Jósvafö, 616 pp.

LATZEL A. (1930): Moose aus dem Komitate Vas u. einigen anderen Komitaten. - Magyar Botanikai Lapok 29: 105-138.

LAWTON E. (1957): A revision of the genus Lescuraea in Europe and North America. - Bulletin of the Torrey Botanical Club 84: 281-307, 337-355.

LAWTON E. (1971): Moss Flora of the Pacific North West. XIII + 362 p. - Nichinan, Miyazaki/Japan: Hattori Botanical Laboratory.

Limpricht K. G. (1895): Die Laubmoose Deutschlands, Oesterreichs und der Schweiz. II. Abtheilung: Bryinae (Stegocarpae [Acrocarpae, Pleurocarpae excl. Hypnaceae]). (= Dr. L. Rabenhorst's Kryptogamenflora von Deutschland, Österrreich und der Schweiz 2. Aufl.) - Leipzig: Kummer, 853 pp.

MAier E. (2001): Leskeaceae, Bestimmungsschlüssel (manuscript). In: NeBEl M. \& PhiliPPI G. (Hrsg.), Die Moose Baden-Württembergs, II. - Ulmer Verlag, Stuttgart, 529 S.

Nebel M. \& Schoepe G. (2001): Leskeaceae. In: Nebel M. \& Philippi G. (Hrsg.), Die Moose BadenWürttembergs, II. - Ulmer Verlag, Stuttgart, 529 S. pp. 245-257.

ORBÁN S. \& VAJDA L. (1983): Magyarország mohaflórájának kézikönyve. - Akadémiai Kiadó, Budapest, p. 426.

PApp B., ERZberger P., Ódor P., Hock Zs., SzövÉNYi P., Szurdoki E. \& Tóth Z. (2010): Updated checklist and red list of Hungarian bryophytes. - Studia Botanica Hungarica 41: 31-59.

Papp B., SzuRdoki E., PAntović J. \& SABovljević M. (2016): Contribution to the bryophyte flora of Mavrovo National Park (Republic of Macedonia). - Studia Botanica Hungarica 47: 279-296.

Purger Z., BAlogh L., PAPP B., RAJCZY M. \& SZMorad F. (1997): A Köszegi-hegység mohaflórája. - TILIA V., Sopron. 94-272.

Ros R. M., Mazimpaka V., Abou-Salama U., Aleffi M., Blockeel T. L., Brugués M., Cros R. M., Dia M. G., Dirkse G. M., Draper I., El-Saadawi W., ErdaĞ A., Ganeva A., Gabriel R., González-Mancebo J. M., Granger C., Herrnstadt I., Hugonnot V., Khalil K., Kürschner H., Losada-Lima A., Luís L., Mifsud S., Privitera M., Puglisi M., Sabovljević M., Sérgio C., M. Shabbara H., Sim-Sim M., SotiauX A., Tacchi R., VANDERPoorten A. \& Werner O. (2013): Mosses of the Mediterranean, an annotated checklist Cryptogamie. - Bryologie 34 (2): 99-283.

SPENCE J. R. (2014): Pseudoleskea. In: Flora of North America Editorial Committee: Flora of North America North of Mexico. - Oxford University Press, New York, Vol. 28: 355-361.

VAJDA L. (1966): A Börzsöny hegység mohaflórája. - Fragmenta Botanica 4., Mus. Hist. Nat. Hung. Budapest, 79-100.

Zare H., Akbarinia M., Hedenäs L. \& MaAssumi A. A. (2011): Eighteen mosses from the Hyrcanian forest region new to Iran. - Journal of Bryology 33: 62-65.

Beérkezett: 2017. 05. 24. • Elfogadva: 2017. 09. 26. 